\title{
The Analysis Potency of Animal Slaughterhouse Retribution and Its Contribution for Pendapatan Asli Daerah (PAD) Pontianak City
}

\author{
Atria Tiffany Widyaningsih \& Sani
}

\author{
Akademi Perpajakan Pontianak \\ Jalan Sultan Abdurrahman No. 8 Kota Baru Pontianak 78124 \\ E-mail: sanni.semm@yahoo.com
}

\begin{abstract}
Regional government financing in performing reliable government duties. This need is increasingly perceived by the region especially since the enactment of regional autonomy in Indonesia, which began on January 1, 2001. With the autonomy, the region is encouraged to be creative to find sources of local revenue that can support regional expenditure financing. From various alternative sources of revenue that may be levied by the regions, the Law on Regional Government setting up local taxes and levies has become a reliable source of revenue for the regions. Since 1984 various Laws on Local Government and financial balance between center and its region. Animal Slaughterhouse that has been built is the only existing RPH in Pontianak City so that its existence is needed by the community in the management and provision of meat that is safe, healthy, whole and kosher for the needs of the surrounding population. Animal Slaughterhouse as a slaughtering business in the provision of healthy meat should consider factors related to sanitation in both the RPH environment and the surrounding environment. In addition to producing meat, RPH also produces additional products that can still be utilized and waste. This research will discuss the potential and contribution of animal slaughtering retribution to Pendapatan Asli Daerah (PAD) Pontianak. The method used in this research is descriptive method, that is method by collecting data which then arranged so that can be made conclusion and suggestion with aim to give systematic and accurate description about the object under research. The data collection techniques conducted by the authors are interviews, observation and documentation. Calculation of the potential of animal slaughterhouse based on the amount of slaughter data. In 2014 - 2016 different with the Realization data in the Department of Agriculture, Fisheries and Forestry of Pontianak City, there is a difference in the number of Retributions of Cutting House Year 2014 of Rp559,327,500, and the difference of slaughterhouse levy in 2015 amounting to Rp612.642.500, whereas in the year 2016 the difference of Levies of Slaughterhouse Rp633.320.000. From the interviews this is due to the slaughter of animals on national holidays which are not levied on retribution fees due to deductions done outside the slaughterhouse but the number of slaughters is recorded as the number of how many animals slaughtered. The existing potential should be explored more deeply because it is a source of local revenue that qualified.
\end{abstract}

Keywords: Animal Slaughterhouse Retribution, Potential, Contribution

\section{INTRODUCTION}

Providing autonomy to regencies and municipalities causes the role of central 
government is getting smaller, on the contrary the regional government will get bigger in development. Regional autonomy is the authority of the autonomous regions to organize and manage the interests according to their own initiative based on the aspirations of the people in accordance with the laws and regulations (Article 1 letter (h) of UU No. 23 of 2014 about Regional Government). The implementation of Law No. 23 of 2014, better known as the Regional Autonomy Law, led to a fundamental change in the regulation of central and regional relations, particularly in the areas of government administration and in financial relations. Responding to the UU, the local government is expected to be more capable and to increase the efforts to explore the financial resources, especially to meet the needs of government financing and development in its area through Pendapatan Asli Daerah.

Regional finance becomes very important and strategic in determining the implementation of governance and regional development. The head of the region is given the authority to explore sources of acceptance that one of them is from local taxes. Regional Autonomy with the aim of enabling the area concerned to be able to regulate and manage their own regional households based on the prevailing laws and regulations. After the issuance of Law no. 28 of 2009 on "Regional Tax and Retribution", where there has been a narrowing for the object of local taxes. So it is not likely to reduce the revenue area of the sector Thus the region is expected to be able to find their own way of solving so that regional revenue from the tax sector does not decrease. This is pursued through efforts to increase the revenues of various sub-sectors of the tax collected by the region, one of subsector tax is animal slaughter tax.

Potential sources of revenue owned by the region will determine the level of financial ability. Each region has different development potential different in accordance with the economic conditions, natural resources, area, and the number of residents so as to provide opportunities for regions to develop themselves in accordance with the potential and conditions. (Hamir, 2007).

In order to welcome the broadest regional autonomy in accordance with the mandate of Law No. 2 of Year 2009 where the portion of taxes and retribution is fully devolved to the Regional Government. One of the taxes referred to is the Animal Slaughter Tax is a very potential source of Local Revenue. With the existence of regional autonomy as well as Law Number 33 Year 2004 about Financial Balance between Central and Local Government encourage the progress in the field of regional economic situation.

Regional tax as one of the components of the Original Regional Income has a very good prospect to be developed. Therefore, the tax should be managed professionally and transparently in order to optimize and increase efforts to contribute to the Original Regional Income. (Yani, 2015). To improve the implementation of Government, Development and Community duties in the Region, then it needs a sufficient amount of funds.

Regional development as an integral part of national development is implemented based on the principle of regional autonomy and the regulation of national resources which provides an opportunity for regional performance improvement to improve the 
welfare of the community towards corruption-free, collusion and nepotism civil society. The implementation of government as a subsystem of local government as a subsystem of state government is intended to increase the efficiency and results of government administration and public service. As an autonomous region, each regions have the authority and responsibility to organize the interests of the society based on the principles of openness, community participation, and accountability to community.

Table 1. Target and Realization Retribution of Cow Slaughter House in Pontianak City Year 2014-2016

\begin{tabular}{rrrr}
\hline Year & Target & Realization (Rp) & Percentage(\%) \\
\hline 2014 & $839.575 .000,00$ & $559.327 .500,00$ & 66.62 \\
2015 & $679.825 .000,00$ & $612.642 .500,00$ & 90.11 \\
2016 & $717.575 .000,00$ & $633.320 .000,00$ & 88.25 \\
\hline
\end{tabular}

Source: Department of Agriculture and Fisheries Affairs, 2018

Local government financing in performing reliable government duties. This need is increasingly perceived by the region especially since the enactment of regional autonomy in Indonesia, which began on 1 st of january 2001. With the existence of autonomy, the region is encouraged to be able to create a source of revenue that can support regional financing expenditure. From various alternative sources of revenue that may be levied by the regions, the Law on Regional Government setting up local taxes and levies has become a reliable source of revenue for the regions. Since 1984 various laws on local government and fiscal balance between central and provinces have placed local taxes and retribution as a source of local revenue, even in Law No. 5 of 1974 local taxes and levies are incorporated into original revenues area. Taxes are one of the largest sources of state revenues, where until now the current potential is still being explored.

Tax collection is necessary in the implementation of a country to improve the welfare and prosperity of this nation that can be achieved with development in all fields. Taxes are now a very important part of the sustainability of the State of Indonesia, as taxes have contributed the most to State revenues. Each region of Indonesia has the right to manage a region with a broad, real and responsible authority that can ensure the development of regional development. RPH is a building or complex of buildings with special design and construction that meet certain technical and hygienic requirements and is used as a slaughterhouse (Permeneg Lingkungan Hidup No 5 Tahun 2014 ).

Animal Slaughterhouse that has been built is the only existing RPH in Pontianak so that its existence is needed by the community in the management and provision of meat that is safe, healthy, whole and halal for the needs of the surrounding population. Animal Slaughterhouse as a slaughtering business in the provision of healthy meat should consider factors related to sanitation in both the RPH environment and the surrounding environment. In addition to producing RPH meat also produces sideways that can be utilized and waste .

target data and the realization of retribution of RPH in Pontianak is presented in table 1. 
From the data above we can see that the realization in 2015 increased from 2014 from $66.62 \%$ to $90.11 \%$, then in 2016 decreased from $90.11 \%$ to $88.25 \%$.

Based on the background that has been described, it can be drawn the formulation of the problem how come Potential Retribution of Slaughterhouse and Contribution of Local Revenue (PAD) of Pontianak City?

\section{LITERATURE REVIEW}

\section{a. Analysis}

One form of analysis is to summarize a large amount of data that is still raw data into information that can be interpreted, categorization or separation of components the relevant components or sections of a set from are also forms of analysis to make the data easily manageable. All forms of analysis attempt to describe patterns consistently in the data so that the results can be learned and translated in a brief and meaningful way.

Based on Wiradi (2013) analysis is an activity that contains a number of activities such as parsing, differentiating, managing something to be classified and regrouped according to certain criteria then searched for and related meaning.

Based on Komarudin, (2013) analysis is the thinking activity to decompose a whole into components so that it can recognize the signs of components, their relationships with each other and their respective functions in a whole that integrated.

\section{b. Potency}

Potential is a capability, ability, power or activity that has the potential to be developed again into a larger form (Madji: 2007). The potential definition is a form of resource or capability that is large enough but the ability has not been unveiled and has not been activated. In short, the potential meaning is unused hidden powers, hidden talents, or unachieved success when in fact we have the power to achieve that success (Myles Munroe).

\section{c. Tax}

In general, the tax is a mandatory contribution to the state owed by individuals or entities that coexist $f$ at Memak sa based law unda ng to not get rewarded in directly and used for the purposes of state for the greatest prosperity of the people, stipulated in the Law No. 16 of 2009.

The definition of tax according to Prof. Dr. Rachmat Soemitro (2013) tax is a levy from people to the Country by Law (enforceable) with is not to perform lead services (contra) directly demonstrated and used to pay general expenses.

In Indonesia, today it is known for various types of taxes and enforced covering various aspects of citizen life. The number of tax experts who provide tax-sharing that has the difference between one with other experts. The different tax divisions are attributed to each expert's perspective on the tax. One division is generally done is based on institution taxes department.

Then the regional government is divided into two, namely the provincial government and district / city government. Thus, the division of tax types according to the collection agency in Indonesia is divided into two, namely the central tax and regional taxes (which is divided into provincial taxes and district / city taxes).

Each level of government can only levy the taxes levied into its powers, and shall not levy any taxes with which it is authorized. This is intended to avoid any overlapping (seizure of authority ) in taxes on society. 
A central tax is a tax stipulated by the central government through legislation, whose powers of imposition are on the central government and the proceeds are used to finance central government spending and development. The central tax is levied by the central government which is administered by the Ministry of Finance of the Republic of Indonesia and the proceeds are used for general household financing.

Local tax is obligatory contribution made by local ang y to the individual or entity without direct rewards, which can be imposed by laws that apply, which are used to finance local government and regional development.

Thus, local taxation is a tax stipulated by local government with regional regulation (Perda), whose collection authority is implemented to finance the expenditure of regional government in implementing regional administration and development. Because of the government provincial and district / municipal governments, which are authorized to implement regional autonomy, local taxes in Indonesia today are also divided into two, namely provincial taxes and district / city taxes.

From the explanation can be drawn conclusions about the difference between taxes with levies. The difference is

1) The nature of the collection of taxes is general, which means applicable for any person eligible for taxation. Meanwhile, the retribution applies only to certain persons, those who enjoy government services that can be appointed.

2) The Institution or collection, Taxes may be collected by the central government or local government while the levies can only be collected by the local government.

\section{d. Retribution}

Retribution are one of the regional income as payment for certain services or licenses specially provided and / or provided by the Regional Government for the interests of an individual or entity. According to Marihot P. Siahaan (2013), levies are regional levies as payment for the services of certain licenses specifically provided and / or provided by the local government for the benefit of individuals or bodies. Services are activities of local government in the form of business and services that cause goods, facilities, or other kemanfatan, can enjoyed by an individual or entity. Similar to the above explanation, if a person wants to enjoy the services provided by the local government, he must pay the retribution stipulated in accordance with applicable regulations.

The types of Retribution distinguished into 3 (three) are as follows:

1) Public Service Retribution

2) Business Services Retribution

3) Specific Licensing

\section{e. Business Service Levies}

Business services are services provided by the Regional Government by adhering to commercial principles because they can basically also be provided by the private sector. The types of business service levies are as follows:

1) Retribution on the use of local wealth

2) Wholesale and / or retail market Retribution

3) Retribution at the auction

4) Terminal Retribution

5) Retribution of special parking spaces

6) Retribution of settlement / house / villa

7) Retribution of slaughterhouses

8) Retribution of port service

9) Retribution of recreation and sports

10) Retribution crossing in water and 
11) Retribution sales of local business production

\section{f. Retribution of Animal Slaughtering}

Pursuant to Perda Pontianak City No. 1 Year 2013 on Amendment to Perda Pontianak City No. 1 Year 2011 on Business Services Retribution, Retribution of Animal Slaughtering is a payment for services for the provision and / or use of facilities Slaughter House Livestock including animal health inspection before the cut that owned and managed by the local government.

Animal Slaughter House (RPH) is a building or building complex with a particular design that is used as a place to cut animals in addition to poultry for consumption of the wider community. Here are the objects and subject Slaughtering Retribution.

1. Object Retribution Animal Slaughtering House

The Object of Animal Slaughter Retribution is a service of providing slaughterhouses, including veterinary inspection services before and after being cut, provided, owned and / or managed by the Regional Government. Excluded from the object of Retribution service provision of livestock slaughtering facilities provided, owned and / or managed by State-Owned Enterprises (BUMN), Regional Owned Enterprises (BUMD) and private parties.

2. Subject of Retribution of Animal Slaughter

The subject of Retribution is an individual or entity that uses / utilizes services for slaughtering and utilization of places in slaughterhouses or slaughterhouses. Mandatory retribution of slaughterhouses is an individual or an entity which, according to the provisions of the retribusi legislation rules, is required to make payments of levy of slaughterhouses, including the levers or cutlery of slaughterhouses.

\section{g. Amount of Slaughterhouse Retribution}

The amount of Slaughterhouse Retribution for the purpose of collection of slaughterhouse Retribution shall be set at 1 (one) $\mathrm{kg}$ of the basic price of each animal specified by Mayor Regulation and will be reviewed every 3 (three) years including:

1. Slaughtering buffaloes, pigs, sheep / sheep recordings for business purposes are as follows:
1) Administration fee $5 \%$
2) Inspection fee before slaughtering process $10 \%$
3) Inspection fee after slaughtering process $15 \%$
4) Maintenance Cost of RPH / TPH $25 \%$
5) Slaughtering costs in RPH $40 \%$
6) Cleaning cost $5 \%$

2. Poultry Chopper cuts for business purposes are as follows:

1) Administration fee 5 permil

2) Inspection fee before slaughtering process 10 permil

3) The cost of inspection after slaughtering 5 permil

4) RPU maintenance cost 30 permil

5) Slaughtering costs in 40 permit RPU

6) RPU cleaning costs 10 permil

3. Slaughtering of livestock and poultry outside the slaughterhouses and slaughterhouses of private poultry animals are subject to retribution fees as an ante mortem and post mortem checking service as follows

1) Slaughtering of poultry per tail shall be subject to retribution fee of 15 permil

2) Slaughtering buffaloes, goats / sheep, pigs the recipient is charged a fee of $25 \%$ 
4. Pontianak Mayor Decision Number 24.1 Year 2012 on the basic price of beef, pork and poultry in the area of Pontianak City Year 2012 set:

1) The average basic meat price referred to is

1. Beef for Rp. 50.000 .00 per $\mathrm{kg}$

2. Pork meat Rp. 40,000.00 per kg

3. Meat Poultry Rp. $10,000.00$ per kg

\section{Sanction Retribution of Slaughter House}

In the case of compulsory levies do not pay on time or less pay, penalized administr ation to a fine of $2 \%$ (two percent) per month from fees payable or underpaid and billed by using the levy levy bill (maximum) 6 (six) months.

\section{h. Procedures for Collection}

Based on the Regional Regulation No. 2 of 2003 on Levies of Animal Cattle and Veterinary Traffic in Pontianak City Levies of Levies can not be raised and the levy payable is collected by using the Regional Levy Bill (STRD) or other similar documents.

\section{i. Billing Procedures}

The Retribution is collected by using a Regional Retribution Letters (STRD) or other equivalent documents and the Decision Letter which causes the amount of levy to be incurred to be incurred and or less paid by the Retribution shall be billed through the State Receivable and Auction Service Office (KP2LN) and levy collection in KP2LN is implemented based on the prevailing laws and regulations.

\section{j . Original Regional Revenue (PAD)}

Based on Law Number 33 Year 2004 regarding Fiscal Balance Between Central and Regional Article 1 point 18 that "Local Revenue, hereinafter referred to as PAD is revenues obtained by areas income according to local regulations in accordance with laws and regulations" which aims to provide flexibility to the region in exploring funding in the implementation of regional autonomy as per the embodiment of the principle of decentralization.

According Warsito (2001: 128) Regional Revenue "Regional Revenue (PAD) is revenue that is sourced and levied itself by the local government. PAD sources consist of: local taxes, regional restitution, profits from regionally-owned enterprises (BUMD), and other legitimate local revenue".

Regional Revenue is one of the funding sources of regional development in fact not enough to contribute to the growth of the region, this is requires local governments to explore and increase local revenues, especially sources of local revenue.

In Law Number 33 of 2004 concerning the financial balance between the central government and regional governments in chapter $\mathrm{V}$ (five) number 1 (one) it is mentioned that the Original Revenue originates from:

\section{Regional Taxes}

The legal basis for the collection of Regional Tax and Regional Levies is Law no. 28 Year 2009 on Regional Tax and Retribution. According to Law No. 28 of 2009 Regional Tax, hereinafter referred to as Tax, is a contribution shall be obliged to the Regions owed by an individual or a coercive body under the Act, without receiving any direct remuneration and used for the purposes of the Regions for the greatest possible prosperity of the people.

Based on Law 28/2009, district / city taxes are divided into the following, Hotel Taxes, Restaurant Taxes, Entertainment Taxes, Advertising Taxes, Street 
Illumination Taxes, Non-Metallic and Rock Mineral Taxes, Parking Taxes, Ground Water Tax, Swallow's Nest Tax , Land and Rural Land and Urban Tax, and Tax on Land and Building Rights Acquisition.

\section{Regional Retribution}

Retribution is a compulsory payment of the people to the State because of certain services provided by the State for its individual population. These services can be said to be direct, ie only pay the retribution only to get / enjoy the remuneration of the State. In accordance with Indonesian laws and regulations, the withdrawal of user charges can only be disbursed by the government area. So, the retribution levied in Indonesia today is local retribution. Levies shall be local levies as payments for services or certain licenses granted exclusively provided and / or provided by local governments for the benefit of individuals or bodies. Services are activities of local government and business and services that cause goods, facilities, or benefits others, may be enjoyed by an individual or entity. If a person wants to enjoy the services provided by the local government, he must pay the levy stipulated in accordance with the applicable provisions.

According to Law Number 28 Year 2009 as a whole there are 30 types of Retribution that can be collected by regions that are grouped into three classes of Retribution, namely general service Retribution, business service fees, and certain licensing fees.

a) Public Service Retribution are services provided or provided by the local government for the purpose of interest and general benefit and can be enjoyed by individuals or entities. b) Business Service Retribution shall be regional levies as payment for business services specifically provided and / or provided by the regional government for the benefit of individuals or bodies.

c) Licensing of Certain Licenses shall be regional Retribution as payment for the granting of a specific permit specifically granted by the regional government for the benefit of an individual or a body.

3. Results of Management of Wealth of Belonging Area

The result of the management of separated property of the region is the revenue of the region derived from the management of separated regional wealth. Law number 33 of 2004 classifies types of regional wealth management results that are separated, broken down according to the income object which includes the share of the return on equity participation in a regional / local-owned enterprise, the share of profits on capital participation in stateowned enterprises / SOEs and the share of return on investments in private-owned companies and community groups.

4. Other Original Regional Original Income

Law Number 33 Year 2004 describes the Original Regional Original Revenue, provided for budgeting of regional revenue not included in the type of tax and the result of separated regional wealth management. These revenues are also regional revenue derived from others belonging to the local government. Law number 33 of 2004 classifies included in legitimate local revenues include:

a) The proceeds from the sale of regional assets which are not separated.

b) Demand deposits.

c) Interest income.

d) Profit is the rupiah exchange rate against foreign currency. 
e) Commissions, deductions, or other forms as a result of the sale, procurement of goods or services by the government.

\section{3 . RESEARCH METHODS}

Method used in this research is descriptive method, that is method by collecting data which then arranged so that can be made conclusion and suggestion with aim to give systematic and accurate description about object studied. From this method can be described the research design as follows.

\section{DISCUSSION}

The potential of regional retribution is the strength that exists in an area to generate a certain amount of regional retribution fees. One of the source of regional retribution is Retribution of Slaughterhouse, to know the potential retribution of an area, among others:

a. The initial condition of an area. The state of the economic and social structure of a region is crucial, namely the size of the regional government's desire to impose retribution and the ability of the community to pay all retributions imposed by the regional government.

b. Increased coverage or extensification and intensification of retribution revenue. Add objects and subjects levies, increase the size of the assignment and reduce arrears

c. Development of Gross Domestic Regional Income per capita. The higher the income of a person, the higher the ability to pay the various charges imposed by the government.

d. Population growth. The amount of income can be affected by the population.

e. Tariff adjustment. Revenue increase is highly dependent on tariff adjustment policies.

f. New development, new revenue sources and regulatory changes a new change will certainly increase local retribution.

Calculation of Potential Levy of Animal Slaughterhouse based on the number of animals cut multiplied by the tariff that has been determined for each type of livestock that is cut. The formula used is as follows:

Table 2. Calculation of Potential Retribution of Animal Slaughtering In Animal Cow, Pig and Poultry Pontianak City

\begin{tabular}{|c|c|c|c|c|c|}
\hline $\begin{array}{l}\text { Animal } \\
\text { Name }\end{array}$ & Year & $\begin{array}{l}\text { Number of } \\
\text { slaughtering } \\
\text { (tail) }\end{array}$ & Total Rates & Calculation & Results \\
\hline \multirow{4}{*}{ Cow } & 2014 & 7741 & \multirow{3}{*}{ Rp 50,000 } & $7741 \times \operatorname{Rp} 50,000$ & $\operatorname{Rp} 387.050 .000$ \\
\hline & 2015 & 7608 & & $7608 \times \operatorname{Rp} 50,000$ & $\operatorname{Rp} 380,400,000$ \\
\hline & 2016 & 8.428 & & $8,428 \times \operatorname{Rp} 50,000$ & $\operatorname{Rp} 421.400 .000$ \\
\hline & 2014 & 14639 & \multirow{3}{*}{$\operatorname{Rp} 40,000$} & $14,639 \times \operatorname{Rp} 40,000$ & Rp 585.560.000 \\
\hline \multirow{3}{*}{ Pork } & 2015 & 14163 & & $14.163 \times \operatorname{Rp} 40,000$ & Rp 566.520.000 \\
\hline & 2016 & 14,566 & & $14,566 \times \operatorname{Rp} 40,000$ & Rp 582.640.000 \\
\hline & 2014 & $5,579,921$ & \multirow{3}{*}{ Rp 10,000} & $5,579,921 \times \operatorname{Rp} 10,000$ & Rp 55.799.210.000 \\
\hline \multirow[t]{2}{*}{ Poultry } & 2015 & 5.272 .023 & & $5.272 .023 x \operatorname{Rp} 10.000$ & $\operatorname{Rp} 52.720 .230 .000$ \\
\hline & 2016 & 5.985 .580 & & $5,985,580 \times \operatorname{Rp} 10,000$ & Rp 59.855.800.000 \\
\hline
\end{tabular}

Source: Processed Data, 2018

Retribution of Animal Slaughtering = The amount of Animal Slaugtered x Rating a. Calculation of Potential Retribution of Animal Slaughter House

Source: Kepwa No 24.1 Year 2012 Pontianak City About Retribution of Animal Slaughtering Place 
For the calculation of the potential magnified in accordance with the tariff rates are already set in Decision Pontianak Mayor Regulation No. 24 .1 2012. About Basic
Price of Beef, Pork and Poultry In Pontianak City Region are as follows:

1. Tariff of Animal cow: Rp50,000 per head

2. Tariff of Animal Pig: Rp40,000 per head

3. Tariff of poultry: Rp10,000 per head

Table 3. Realization and Potential Amount Retribution of Animal Slaughter 2014 to 2016 Pontianak City

\begin{tabular}{|c|c|c|c|c|c|c|c|}
\hline \multirow{2}{*}{ Year } & \multirow{2}{*}{$\begin{array}{l}\text { Realization } \\
\quad \text { (Rp) }\end{array}$} & \multicolumn{3}{|c|}{ Potential (Rp) } & \multirow[t]{2}{*}{$\begin{array}{c}\text { Potential } \\
\text { Amount (Rp) }\end{array}$} & \multirow[t]{2}{*}{$\begin{array}{c}\text { Potential } \\
\text { unexplored }\end{array}$} & \multirow[t]{2}{*}{$\begin{array}{c}\text { Levies are } \\
\text { not collected }\end{array}$} \\
\hline & & Cow & Pork & Poultry & & & \\
\hline 1 & 2 & 3 & 4 & 5 & $6(3+4+5)$ & $7(2-6)$ & $8(6-7)$ \\
\hline 2014 & 559.327 .500 & 387.050 .000 & 585.560 .000 & 55.799 .210 .000 & 56.771 .820 .000 & 56.212 .492 .500 & 559.327 .500 \\
\hline 2015 & 612.642 .500 & 380.400 .000 & 566.520 .000 & 52.720 .230 .000 & 53.667 .150 .000 & 53.054 .507 .500 & 612.642 .500 \\
\hline 2016 & 633.320 .000 & 421.400 .000 & 582.640 .000 & 59.855 .800 .000 & 60.859 .840 .000 & 60.226 .520 .000 & 633.320 .000 \\
\hline
\end{tabular}

The greatest potential is in the poultry sector. At the same time, the amount of Retribution Potential is bigger than Pontianak Livestock Retribution Realization data, this is caused by the not paying of Slaughtering house Retribution at national holidays (Idul Fitri, Christmas, Idul Adha and Chinese New Year) but the data slaughter of animals remains in the input into the number of data slaughter. To compare the realization of slaughterhouse retribution acceptance with its potency and levy that can not be collected can be seen in Table 3 below

\section{b. Contribution of Retribution of Animal Slaughtering House to Regional Original Income (PAD) Pontianak City}

This calculation is used to find out how big the contribution of Retribution of Animal Slaughtering House to Revenue Original Area, with formula as follows:

Contribution Levy RPh
$=\frac{\text { Realizing of RetributionAnimal Slautering }}{\text { PAD }}$

Based on Table 4 can be seen Contribution Retribution of Animal Slaughtering House of Original Revenue Pontianak. In 2014, the contribution of RPH levy is $0.187 \%$, and 2015 decreased to $0.183 \%$, while in 2016 decreased to $0.162 \%$, so the contribution of slaughterhouse levy to original revenue (PAD) tended to decrease and not increase.

\section{c. Inhibiting Factor In Amount of Retribution of Animal Slaughterhouse}

Based on the result of interview with Sub Department of Agriculture, Fishery and Forestry Development of Pontianak City , the obstacle factor in acceptance of slaughterhouse retribution is as follows:

\section{a. Debt Factor}

The number of cow ranchers who at the time of cutting does not pay direct retribution to the collector of slaughterhouse retribution but the data of slaughter of cow has entered into the number of potential cow that are slaughter so that affect the income of retribution to be deposited into the cash area of Pontianak City.

\section{b. Animal Size Factor}

Many cow ranchers who pay retribution based on the size of the cow that will be slaughter, if the size of a small cow then the cow ranchers will reduce the tariff retribution of Animal Slaughter House that has been established Pontianak Mayor Regulation so it is very influential on the revenue of Pendapatan Asli Daerah (PAD) Pontianak 


\section{c. Cow Slaughtering Outside Animal Cutting House (RPH)}

The cattle ranchers often do cattle slaughtering outside the cow RPH so that the
RPH levy collector has difficulty in data collection of cow slaughter and can harm the original income of Pontianak

Table 4. Contribution of Retribution of Animal Slaugtering Year 2014 to 2016 Pontianak City

\begin{tabular}{ccrr}
\hline Year & $\begin{array}{c}\text { Realization of RPH } \\
\text { Retribution (Rp) }\end{array}$ & Original Revenue (Rp) & $\begin{array}{c}\text { Contribution } \\
(\%)\end{array}$ \\
\hline 2014 & 559.327 .500 & $298.768 .480 .274,53$ & 0.187 \\
2015 & 612.642 .500 & $334.673 .293 .035,9$ & 0.183 \\
2016 & 633.320 .000 & $389.368 .618 .493,49$ & 0.162 \\
\hline
\end{tabular}

Source: Processed Data, 2018

For those of the Technical Implementation Unit (UPTD) Slaughterhouse held inspection for each slaughtering process outside the slaughterhouses of cow and issuing a notice or warning to the cow ranchers who are less obey the rules that have been established by the Government of Pontianak City as a result of these factors to avoid delays and delays in depositing Retribution to the Regional Treasury.

\section{CONCLUSION AND SUGGESTION}

\section{Conclusion}

Based on the discussion of this research results the authors can be drawn conclusions as follows:

a. Calculation of the potential of slaughterhouse retribution based on the amount of slaughter data In 2014 to 2016 different with the existing Realization data in the Department of Agriculture, Fisheries and Forestry of Pontianak City, there is a difference in the amount of Retribution of Slaughterhouse Year 2014 of Rp559,327,500, and the difference of slaughterhouse retribution in 2015 amounting to Rp612.642.500, whereas in the year 2016 the difference of Retribution of Slaughterhouse Rp633.320.000. From the interviews this is due to the slaughter of animals on national holidays that are not calculated on retribution fees because the deduction is done outside the slaughterhouse, but the number of deductions is recorded as the number of animals slaughter.

b. Tariff on Retribution of Animal Slaughter House based on Pontianak Mayor Regulation Decree No 24.1 of 2012 About Basic Price of Beef, Pork and Poultry In Pontianak City Region, based on interview result of slaughterhouse retribution is in accordance with the regulation applied by the Government of Pontianak City.

c. The contribution of slaughterhouse livestock tending in animals tended to decrease and did not increase, whereas the percentage of Realization of Levy of Animal Slaughtering in beef in 2014 was only $0.187 \%$ and decreased in 2015 to $0.183 \%$, while in 2016 decreased to $0.162 \%$ of total Pendapatan Asli Daerah (PAD) of Pontianak City

\section{Suggestion}

Based on the above conclusions, the suggestions to be conveyed by the author are:

a. Pontianak Municipal Government should raise Retribution Rate is one way to increase Retribution Slaughter House in 
Pontianak City and increase the original income of Pontianak City.

b. Pontianak Municipal Government should provide intensive extension to mandatory Retribution of Slaughterhouse on the rights and obligations as well as benefits from fees paid.

c. Preferably the Officers of Retribution of Animal Vehicle Picking Up or inspection it is mandatory that new retribution has not been subject to previous retribution by increasing inspection and supervision activities in the field.

d. We recommend that the retribution collector Household Pontianak City does not allow the obligation to pay the retribution indirectly or in debt, because it can reduce revenue Original Regional (PAD) Pontianak.

\section{BIBLIOGRAPHY}

Komarudin, Achmad. (2013). Psikologi Olahraga. Bandung: PT. Remaja Rosdakarya.

Madji, Udo Yamin. (2007). Qur'anic Quotient, Qultum Media. Jakarta.

Siahaan, Marihot Pahala. (2013). Pajak Daerah dan Retribusi Daerah. Jakarta: PT Raja Grafindo Persada.

Soemitro, Rochmat. (2013). Asas dan Dasar Perpajakan 1. Bandung: PT. Refika Aditama.

Wiradi, Gunawan. (2013). Analisis Sosial. Jakarta: PT. Rineka Cipta.

Yani, Ahmad. (2015). Hubungan Keuangan Pemerintah Pusta dan Daerah di Indonesia. Edisi Revisi. Jakarta: PT. Rajawali Press.

Peraturan Daerah Nomor 1 Tahun 2013 tentang Perubahan atas Perda Kota Pontianak Nomor 1 Tahun 2011 tentang Retribusi Jasa Usaha.
Keputusan Walikota Pontianak Nomor 24.1 Tahun 2012 tentang Harga Dasar Daging Sapi, Babi, dan Unggas dalam Wilayah Kota Pontianak.

Peraturan Daerah Nomor 2 Tahun 2003 tentang Retribusi Potong Hewan dan Lalu lintas Hewan Kota Pontianak.

Undang-Undang Nomor 28 Tahun 2009 tentang Pajak dan Retribusi Daerah.

Undang-Undang Nomor 33 Tahun 2004 tentang Perimbangan Keuangan Antara Pusat dan Daerah.

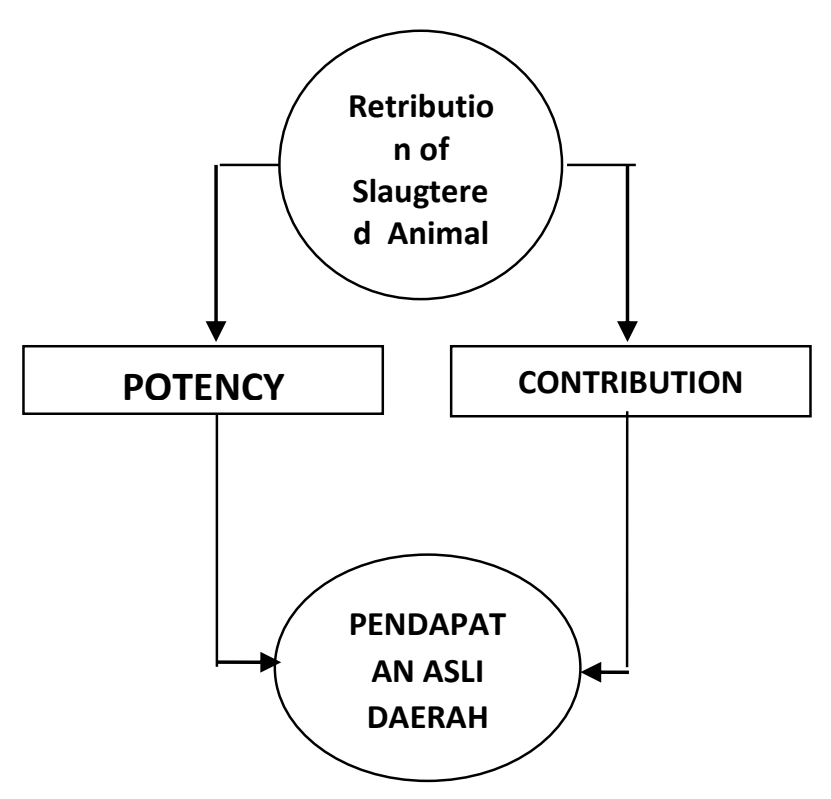

Figure 1. Research design 
